A Time for Tea

A John Hope Franklin Center book 



\section{A Time for Tea}

WOMEN, LABOR, AND POST/COLONIAL

POLITICS ON AN INDIAN PLANTATION

Piya Chatterjee 
(C) 200I Duke University Press

All rights reserved

Printed in the United States of America

on acid-free paper @

Designed by C. H. Westmoreland

Typeset in Fournier

by Tseng Information Systems, Inc.

Library of Congress Cataloging-in-Publication

Data appear on the last printed page

of this book. 
for Baba, my father who mothers me

for Kaki, who does the same

for Kaku, who is gentle

and in memory of my mother,

Dipti Chatterjee, who wished it 
